\title{
Вариолитовые лавы базальтов Мауранипурского зеленокаменного пояса Бунделкханского кратона Индийского щита
}

\author{
Светов С.А. ${ }^{1}$, Сингх В.К. ${ }^{2}$, Чаженгина С.Ю. ${ }^{1}$, Рыбникова 3.П. ${ }^{1}$, Гоголев М.А. ${ }^{1}$, Мишра С. ${ }^{3}$ \\ ${ }^{1}$ Институт геологии КарНЦ РАН, Петрозаводск, ssvetov@krc.karelia.ru \\ ${ }^{2}$ Геологический факультет Бунделкхандского университета, Джанси, Индия, \\ vinodksingh@bujhansi.ac.in \\ ${ }^{3}$ Геологический факультет университета Хемвати Нандан Бахугана Гарваль, Индия, \\ smpsgeo@gmail.com
}

Аннотация. В результате изучения мезоархейской базальтовой ассоциации зеленокаменного пояса Мауранипур (Бунделкханский кратон, Индийский щит) установлено существование в разрезе вариолитовых лав (подушечных и массивных), в которых ярко проявлен процесс силикатной несмесимости (сосуществования двух расплавов базальтового и андезидацитового состава). Несмесимость маркируется наличием вариолей (глобул) контрастного химического состава по отношению к основному матриксу и процессами коалесценции с образованием линзовидных скоплений ликвата в ядрах подушечных лав и кровле массивных потоков. Вероятно, их образование связано с процессами «низкотемпературной» метастабильной ликвации, проходящей в режиме «in situ» в пределах лавовых потоков, покровов или отдельных подушек после их излияния.

Ключевые слова: Архей, Банделькханский кратон, зеленокаменный пояс, базальты, вариолитовые лавы.

\section{Variolithic lavas of basalts of the Mauranipur greenstone belt of the Bundelkhand craton, Indian Shield}

\author{
Svetov S.A. ${ }^{1}$, Singh V.K. ${ }^{2}$, Chazhengina S.Y. ${ }^{1}$, Rybnikova Z.P. ${ }^{1}$, Gogolev M.A. ${ }^{1}$, Mishra S. ${ }^{3}$ \\ ${ }^{1}$ Institute of Geology, Karelian Research Centre RAS, Petrozavodsk, Russia, ssvetov@krc.karelia.ru \\ ${ }^{2}$ Department of Geology, Bundelkhand University, Jhansi, India, vinodksingh@bujhansi.ac.in \\ ${ }^{3}$ Department of Geology, Hemvati Nandan Bahuguna Garhwal University, Srinagar-Garhwal, India, \\ smpsgeo@gmail.com
}

\begin{abstract}
The pillow and massive variolitic lavas with the signs of silicate immiscibility were documented firstly for the Mesoarchean basalt series from Mauranipur greenstone belt. The silicate immiscibility is indicated by occurrence of the varioles (globules) with the differing chemical composition compared to matrix along with the coalescence processes marked by the formation of lense clusters in the cores of the pillow lavas and top of the lava flows. The formation of the variolated structure might be caused by the «low-temperature» metastable liquation occurring «in situ» within the lava flows, lava beds and lava pillows after eruption.
\end{abstract}

Key words: Archean, Bundelkhand craton, greenstone complex, basalts, variolithic lavas.

\section{Introduction}

Variolitic (globular) lavas are widely distributed in the basalt and andesite-basalt associations from the Archean to Phanerozoic. Usually its genesis is considered to be connected with various processes including 1) liquation differentiation, supposedly the differentiation of initially homogeneous silicate melt into several immiscible phases, which can either be crystallized simultaneously or separated due to the gravitational fractionation (Greig, 1927; Gelinas, 1974; Veksler et al., 2007); 2) crystallization of spherulites during melt overcooling (Zavaritskii, Sobolev, 1961).

Up to now, a lot of field geological observations of liquid silicate immiscibility were obtained for various rocks (Fergusson, 1972; Gelinas et al., 1976; Hanski, 1993; Fovler et al., 2002; Krassivskaya et al., 2010), however the most abundant manifestation of it is the variolite formation in the basalt lavas. From the 1970s, the numerous studies have revealed the variolotic lavas from the Archean basalt komatiites of the Barberton greenstone complex (South Africa) (Fergusson et al., 1972), tholeiitic lavas from the RouynNoranda area of the Abitibi greenstone belt (Canada) (Gelinas et al., 1976), basalt lava lakes of the Kilauea and Makapuhi volcanoes (Hawaii islands), iron-rich basalts in Greenland (Anderson, Gottfried, 1971) and others. 


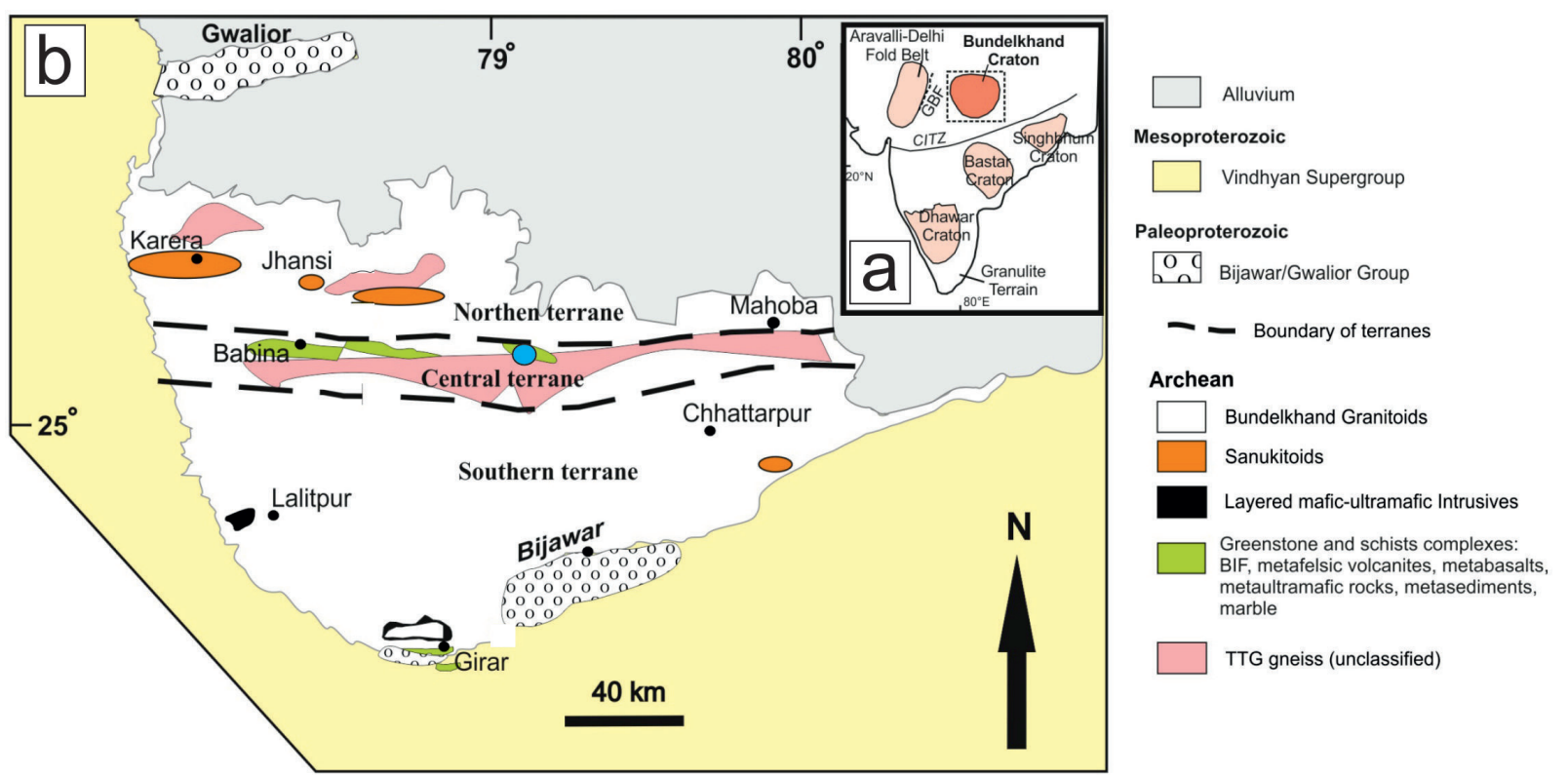

Fig. 1. (a) Scheme of the cratonic blocks of the Indian Shield; (b) map showing the tectonic division of the Bundelkhand Craton (Slabunov \& Singh 2019).

Рис. 1. (a) Схема кратонов Индийского щита; (b) схема тектонического районирования Бунделкхандского кратона (Slabunov \& Singh 2019).

Field trips made in 2017-2018 in order to study the Mesoarchean mafic sequences of the Bundelkhand Craton (Indian Shield) revealed a few types of variolitic lavas from Mauranipur greenstone belt that had never been reported earlier.

\section{Geological setting}

The Indian Shield consists of few segments of the Archean cratons, including the Dharwar, Bastar, Singhbhum, Avali, and Bundelkhand craton (Fig. 1, a) represented by, represented by distinguishing rock sequences characterized by different geological genesis. The study was carried out within the central terrain of the Bundelkhand Craton (Babina-Mauranipur-Mahoba area) composed of granite-greenstone complex represented by the Paleo-Neoarchean tonalite-trondhjemite-granodiorite (TTG), Paleoarchean oceanic rocks, Mezo-Neoarchean greenstone rocks, and Neoarchean granodiorite-granite suits (Singh et al., 2019 a; Singh et al., 2019b).

The sections of Mezoarchean (2.8 Ga) greenstone rocks were mostly wwell-preserved in the Babina and Mauranipur Belts (Fig. 1 b), formed by the mafic lavas, felsic volcanics, and metasedimentary rocks (BIF). The mafic sequence is cut by the Neoarchean felsic dykes dated at 2557 $\pm 33 \mathrm{Ma}$ (Slabunov, Singh, 2018).

The detailed geological survey in the Mauranipur greenstone belt revealed the relict of the sequence of Mezoarchean mafic assemblages with the thickness of $600 \mathrm{~m}$ (Baragaon locality), and, additionally, small (up to $100 \mathrm{~m}^{2}$ ) xenoliths of pillow lavas preserved in the Neoarchean granitoids (Madha locality, streambed of the River Sukhnai Nadi). The bottom section of mafic assemblage is represented by pillow lava flows (or lava beds) with the thickness varying from 10-15 to $70 \mathrm{~m}$. The lavas contain closely packed strike elongated pillows with the long axis length from $30 \mathrm{~cm}$ to $2 \mathrm{~m}$. The pillows are characterized by zoned structure marked by the coarsely grained central part and fine grained chilg rims (up to $3 \mathrm{~cm}$ ). Spaces between pillows are filled with tuff material with clastic and chemogenic siliceous mixtures. Some pillows indicated the direction of the top of the lava flow.

\section{Variolitic lava texture}

It is noteworthy that the indication of some strata with the signs of liquid immiscibility among the pillow lava flows is of great importance. на In this case, the pillow lavas have a variolitic structure in the pillow cores (Fig. 2, a) presented by either separate rounded varioles, i.e., globules from 1-2 $\mathrm{mm}$ to $5 \mathrm{~cm}$ 
in size with differing color and composition compared with the host rock or lenses produced by the variole coalescence (Fig. 2 b, c). The effect of liquid immiscibility on crystallization is evidenced by the fractional zoning of pillows (Fig. 2b) with the following distinguished zones: (1) chilg zone with the thickness $<2$ $\mathrm{cm}$; (2) boundary massive fine grained zone with the thickness 1-6 cm; (3) light zone in the pillow core produced by the coalescence of globules; (4) zone of separate globules and matrix; (5) zone with relict matrix in the pillow core.

It should be mentioned that pillow lava assemblages are interbedded with strata of volcanogenic sedimentary rocks of low thickness. The top and middle parts of the section along with the pillow lavas the massive, amygdaloidal and variolitic lavas are abundant. The thickness of these flows reaches 15-20 m. In variolitic lavas, the concentration of varioles increases from the bottom to the top. In top and central parts of the flow, there are variole producing lense clusters alternating with matrix, in which separate varioles can be observed. This alternation of liquation strata with varying thickness is marked by the change of dark
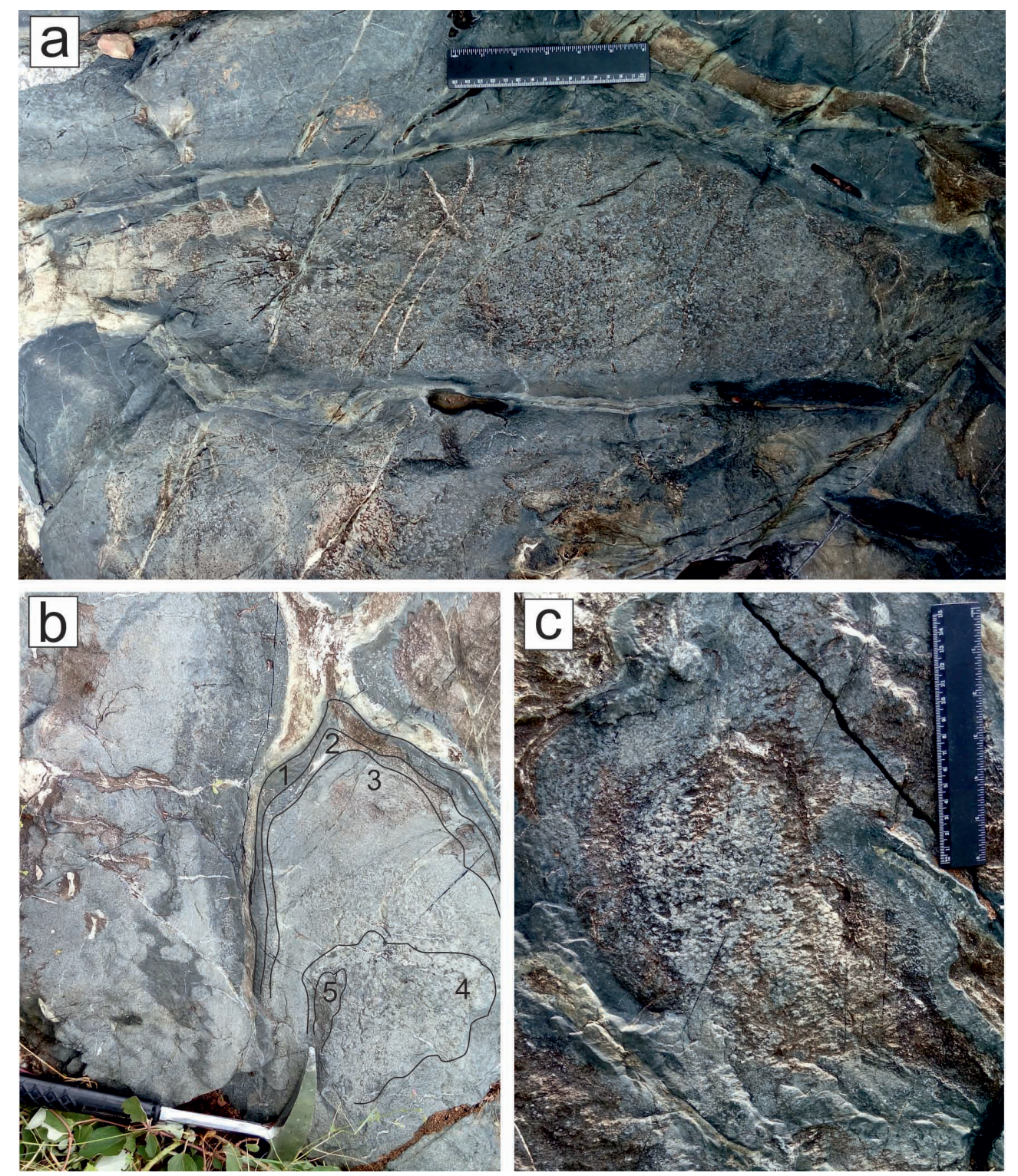

Fig. 2. Photographs of field occurrence of pillow lavas from basalts in the Mauranipur greenstone belt. $\mathrm{a}$ - overview and packing of pillows; $\mathrm{b}$ - liquation zoning in pillows (numbers are noted in the text); $\mathrm{c}$ - the formation of the pillow cores due to the coalescence of separate globules.

Рис. 2. Фотографии обнажений подушечных лав базальтов зеленокаменного пояса Мауранипур. $\mathrm{a}$ - общий вид подушек и характер их упаковки; $\mathrm{b}$ - пример ликвационной зональности в подушках (цифры описаны в тексте); с - формирование ядер в подушках за счет слияния отдельных глобул. 
green grey color to the light green grey color of the rocks observed in the deposits. The lavas are traced along the strike direction for 150-200 $\mathrm{m}$. In the bottom of the section, the mafic rocks are cutted by diorite dykes and quartz veins. Intrusive bodies are presented by the ultramafic rocks. The studied rock sequence experienced tectonical deformations and was metamorphosed in amphibolite facies. The primary minerals were substituted by secondary mineral assemblage including hornblende, magnetite, epidote, albite, and quartz, but the initial rock texture was preserved.

\section{Chemical composition}

According to the chemical composition, the mafic assemblage is classified as calc-alkaline basaltandesite. Malvia et al. (2006) assumed that this complex could be attributed to oceanic komatiitic, according to the authors to island-arc tholeiitic (IAT) complexes.

The analysis of variolate morphology and chemical composition of globules and matrix was provided with a VEGA II LSH (Tescan) scanning electron microscope accompanied by a INCA Energy 350 energy dispersive detector in the Analytical Centre of the Institute of Geology, Karelian Research Centre, RAS. Since the chemical composition of variolate was determined by the microprobe analysis, the FeO content was evaluated as total.

The concentration of major elements in the globule-matrix system were analyzed using the detailed square scanning (Fig. 3). $\mathrm{SiO}_{2}$ content in globules varies from 53.5 to 65.8 wt. \%, $\mathrm{Al}_{2} \mathrm{O}_{3}$ from 13.6 to 18.5 wt. $\%, \mathrm{FeO}{ }_{\text {tot }}$ from 5.7 to 8.4 wt. $\%, \mathrm{MgO}$ from 4.9 to 7.5 wt. $\%, \mathrm{CaO}$ from 5.8 to 10.1 wt. $\%, \mathrm{Na}_{2} \mathrm{O}$ from 3.3 to 6.8 wt. $\%$, and $\mathrm{K}_{2} \mathrm{O}$ from 0.7 to 3.9 wt. \%. Variole composition corresponds to the sub-alkaline andesite rocks with $\left(\mathrm{Na}_{2} \mathrm{O}+\mathrm{Ka}_{2} \mathrm{O}\right)$ content ca. 3-10 wt. \%.

In the binary diagrams (Fig. 3), the whole-rock, variole and matrix compositions follow the common trends of fractionation with $\mathrm{R} 2>0.94$ for stable components $\left(\mathrm{FeO} *, \mathrm{Al}_{2} \mathrm{O}_{3}\right)$. It might be the evidence of initial crystallization of single primary basalt melt with its further differentiation of into two phases, i.e.,
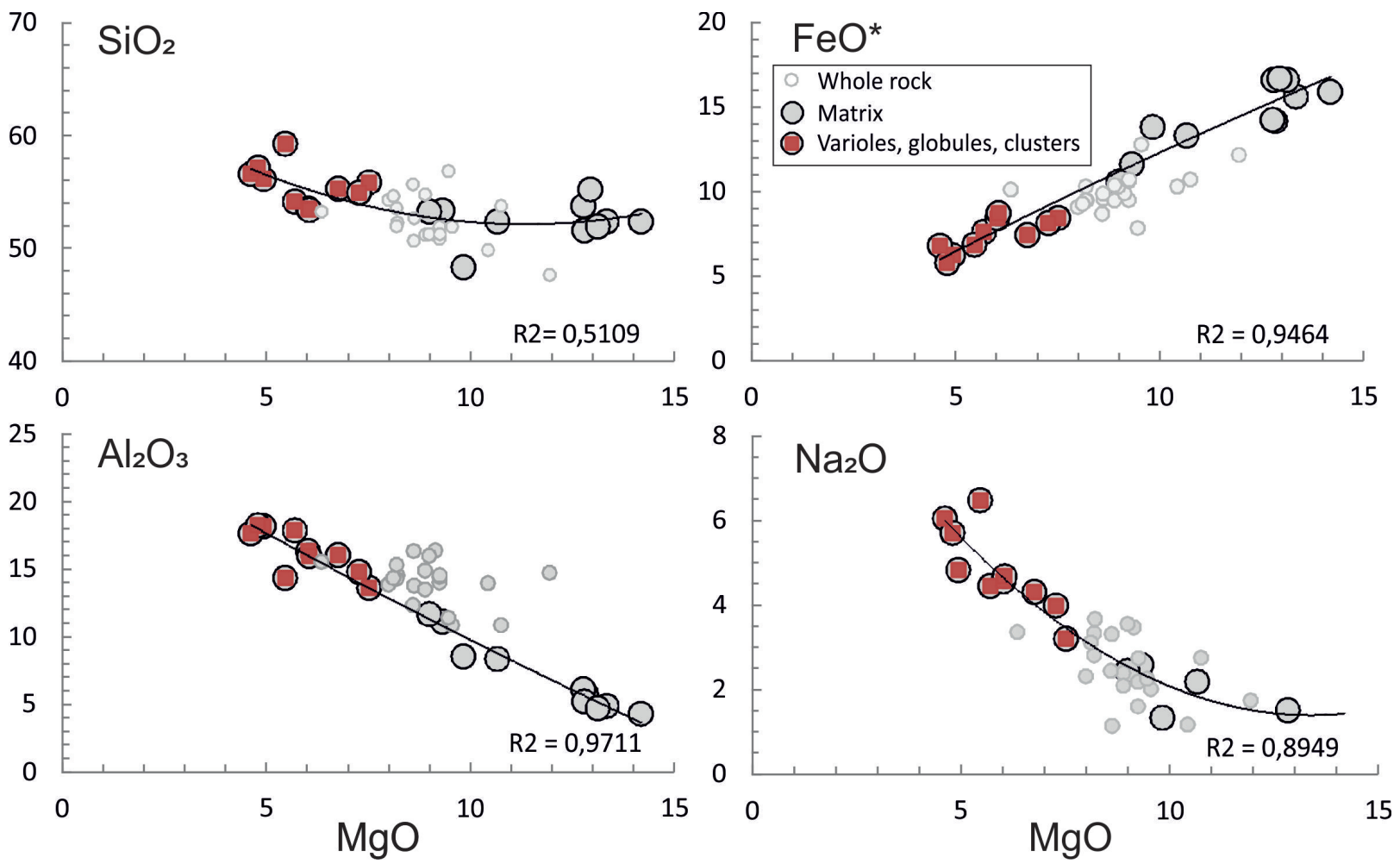

Fig. 3. Binary variation diagrams of $\mathrm{SiO}_{2}, \mathrm{FeO}^{*}{ }_{\text {(total) }}, \mathrm{Al}_{2} \mathrm{O}_{3}, \mathrm{Na}_{2} \mathrm{O}$ versus $\mathrm{MgO}$ content in whole-rock, matrix and varioles from variolitic lavas of the Mauranipur greenstone belt.

Рис. 3. Бинарные диаграммы $\mathrm{SiO}_{2}, \mathrm{FeO}^{*}{ }_{\text {(total) }}, \mathrm{Al}_{2} \mathrm{O}_{3}, \mathrm{Na}_{2} \mathrm{O}-\mathrm{MgO}$ для ликвационных образований (вариолей, матрикса, пород в целом) зеленокаменного пояса Мауранипур. 
felsic phase composed globules and lenses and mafic phase composed matrix. Concomitantly, the deviations of $\mathrm{SiO}_{2}$ and alkali, particular $\mathrm{Na}_{2} \mathrm{O}$, contents from the fractionation trends are observed (Fig. 3). The data reflect the redistribution of these components due to their mobility in the metamorphic processes.

\section{Conclusions}

The variolitic lavas (pillow and massive) with the signs of silicate immiscibility were documented firstly for the Mesoarchean basalt series from the Mauranipur greenstone belt. The silicate immiscibility is indicated by occurrence of the varioles (globules) with the differing chemical composition compared to matrix along with the coalescence processes marked by the formation of lenses clusters in the cores of the pillow lavas and top of the lava flows. The formation of the variolated structure might be caused by the low-temperature metastable liquation occurring in situ within the lava flows, lava beds and lava pillows after eruption. The differentiation trend moves toward the formation of more felsic and alkaline rich silicate phases, whereas the residual matrix is enriched with $\mathrm{FeO}$ (up to $18 \mathrm{wt} . \%$ ) and $\mathrm{MgO}$ (up to $14 \mathrm{wt}$ \%). It is the fluid phase that might provide the trigger mechanism for the liquation processes.

\section{Acknowledgement}

This research was partially supported by RFBR N 17-55-45005 through the Collaboration Program between Karelian Research Centre, RAS, Petrozavodsk, Russia and Bundelkhand University, India. The financial support for the research was from the Federal budget for the implementation of the state order.

\section{Reference}

1. Anderson A.T, Gottfried D. Contrasting behaviour of $\mathrm{P}, \mathrm{Ti}$ and $\mathrm{Nb}$ in a differentiated high-alumina olivinetholeiite and a calc-alkaline andesite suite // Geol Soc Am Bull. 1971 82. P. 1929-1942. Doi.org/10.1130/00167606(1971)82[1929:CBOPTA]2.0.CO;2.

2. Fergusson J. Silicate immiscibility in the ancient basalts of the Barberton Mountain Land, Traansvaal // Nat. Phys. Sci. 1972. 235. P. 86-89.

3. Fowler A.D., Berger B., Shore M. Supercooled rocks: development and significance of varioles, spherolites, dendrites and spinifex in archaean volcanic rocks, Abitibi greenstone belt. Canada // Precambrian Res. 2002. 115. P. 311-328.

4. Gelinas L. Textural and chemical evidence of liquid immiscibility in variolitic lavas // Abstr. Am. Geophys. Union. 1974. 55. P. 486.

5. Gelinas L., Brooks C., Trzcienski W. E. Archean variolites quenched immiscible liquids // Can. J. Earth Sci. 1976. 13. P. 210-230.

6. Greig J. W. Immiscibility in silicate melts // Am. J. Sci. 1927. 73. P. 133-154.

7. Hanski E. J. Globular Ferropicritic Rocks at Pechenga, Kola Peninsula (Russia): Liquid Immiscibility Versus Alternation // Lithos. 1993. 29. P. 197-216.

8. Krassivskaya I.S., Sharkov E.V., Bortnikov N.S., Chistyakov A.V., Trubkin N.V., Golovanova T.I. Variolitic lavas in the axial rift of the mid-atlantic ridge and their origin (Sierra Leone area, $6^{\circ} 18^{\prime} \mathrm{N}$ ) // Petrology. 2010. 18 (3). P. 263-277.

9. Malviya V.P., Arima M., Pati J.K., Kaneko Y. Petrology and geochemistry of metamorphosed basaltic pillow lava and basaltic komatiite in the Mauranipur area: subduction related volcanism in the archean Bundelkhand craton, Central India // Journal of Mineralogical and Petrological Sciences. 2006. 101(4). P. 199-217. DOI: $10.2465 /$ jmps.101.199.

10. Singh P.K., Verma S.K., Moreno J.A., Singh V.K., Malviya P.K., Oliveira E.P., Mishra S., Arima M. Geochemistry and Sm-Nd isotope systematics of metabasalts from the Babina and Mauranipur greenstone belts, Bundelkhand craton: Implications for tectonic setting and Paleoarchean mantle evolution // Lithos. 2019 a. 330-331. P. 90-107. https://doi.org/10.1016/j.lithos.2019.02.010.

11. Singh P.K., Verma S.K., Singh V.K., Moreno J.A., Oliveira E.P., Mehta P. Geochemistry and petrogenesis of sanukitoids and high-K anatectic granites from the Bundelkhand craton: Implications for the late-Archean crustal evolution // Journal of Asian Earth Sciences. 2019 b. 174. P. 263-282. https://doi.org/10.1016/j. jseaes.2018.12.013.

12. Slabunov A.I., Singh V.K. Meso-Neoarchaean crustal evolution of the Bundelkhand Craton, Indian Shield: new data from greenstone belts // International Geology Review. 2019. 61. P. 1409-1428. Doi.org/10.1080/0 0206814.2018.1512906.

13. Veksler I., Dorfman A., Borisov A., Wirth R., Dingwell D. Liquid immiscibility and the evolution of basaltic magma // J. Petrol. 2007. 48. P. 2187-2210.

14. Zavaritskii A. N., Sobolev V. S. Physicochemical principles of petrography of igneous rocks. Gosgeoltekhizdat, Moscow. 1961. 400 p. [in Russian].

15. Slabunov A.I., Singh V.K. The new tectonic division of the Bundelkhan craton, Indian shield // Abstract of Fersman Scientific Conference. Apatity. 2019. 16. P. 521-524. https://doi.org/10.31241/FNS.2019.16.106\$. 